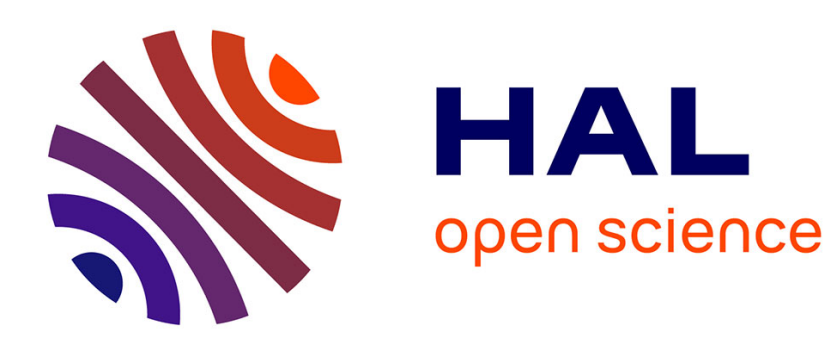

\title{
Three-dimensional printing, muscles, and skeleton: mechanical functions of living wood
}

Bernard Thibaut

\section{To cite this version:}

Bernard Thibaut. Three-dimensional printing, muscles, and skeleton: mechanical functions of living wood. Journal of Experimental Botany, 2019, 70 (14), pp.3453-3466. 10.1093/jxb/erz153 . hal02315022

\section{HAL Id: hal-02315022 \\ https://hal.science/hal-02315022}

Submitted on 14 Oct 2019

HAL is a multi-disciplinary open access archive for the deposit and dissemination of scientific research documents, whether they are published or not. The documents may come from teaching and research institutions in France or abroad, or from public or private research centers.
L'archive ouverte pluridisciplinaire HAL, est destinée au dépôt et à la diffusion de documents scientifiques de niveau recherche, publiés ou non, émanant des établissements d'enseignement et de recherche français ou étrangers, des laboratoires publics ou privés. 


\title{
Three-dimensional printing, muscles, and skeleton: mechanical functions of living wood
}

\author{
Bernard Thibaut ${ }^{*}$ (i) \\ Laboratoire de Mécanique et Génie Civil, Université de Montpellier, CNRS, Montpellier, France \\ * Correspondence: bernard.thibaut@umontpellier.fr
}

\begin{abstract}
Wood is well defined as an engineering material. However, living wood in the tree is often regarded only as a passive skeleton consisting of a sophisticated pipe system for the ascent of sap and a tree-like structure made of a complex material to resist external forces. There are two other active key roles of living wood in the field of biomechanics: (i) additive manufacturing of the whole structure by cell division and expansion, and (ii) a 'muscle' function of living fibres or tracheids generating forces at the sapwood periphery. The living skeleton representing most of the sapwood is a mere accumulation of dead tracheids and libriform fibres after their programmed cell death. It keeps a record of the two active roles of living wood in its structure, chemical composition, and state of residual stresses. Models and field experiments define four biomechanical traits based on stem geometry and parameters of wood properties resulting from additive manufacturing and force generation. Geometric parameters resulting from primary and secondary growth play the larger role. Passive wood properties are only secondary parameters, while dissymmetric force generation is key for movement, posture control, and tree reshaping after accidents.
\end{abstract}

Keywords: Additive manufacturing, fibre, muscle function, skeleton function, tracheid, tree biomechanics, wood.

\section{Introduction}

Trees are a specific type of plants with a characteristic woody compartment, which is both aerial and subterranean, that allows them to exploit very large resources: that is, solar energy and nutrients above and below ground. The perennial woody part of a tree is a 'tree-like' structure, made of cantilever beams, which grows in dimension and mass throughout the whole of the tree's life. The aerial part of the woody structure, which is discussed in this review, has to perform some basic mechanical functions: (i) give progressively higher and progressively larger support to the canopy, which captures sunlight (i.e. manufacture of structure); (ii) resist external forces, which are mainly due to gravity and wind loads (i.e. mechanical resistance); (iii) control and eventually restore the prescribed posture of the structure (i.e. posture control); and (iv) provide a network of conduits resistant to the pressure needed for sap flow (i.e. a hydraulic system).

Wood is the natural tissue that forms the bulk of all the woody parts - the trunk, branches, and roots—located under the bark, and is described in biological reference books (e.g. Raven et al., 2007). Unlike the wood used as an inert engineering material, as described in technical reference books (e.g. Forest Products Laboratory, 2010), wood inside the tree is a living tissue that is actively involved in the four mechanical functions described above (Déjardin et al., 2010). Of course, the functions of wood in the tree are not only mechanical. Wood also plays essential roles in the flow of nutrients and information between the roots and canopy, and in the storage of water and nutrients. 
Biomechanics is basically the engineering mechanics of living beings, in which biological phenomena have to be taken into consideration in the basic equations relating force to movement and stress to strain. The aim of this paper is mainly to examine life-induced parameters in living wood that are important for tree mechanics: that is, changes in geometry, changes in mass, force generation, and torque generation.

\section{Some concepts and terms}

\section{Life, cell, and fibre}

Mechanics and biology often use identical technical terms for slightly different objects or concepts, such as 'life', 'cell', or 'fibre'. In mechanical engineering, 'life' is used to describe working duration, as in life cycle analysis (i.e. 'from cradle to grave'); this review will use long (or short) lasting in this case. Life for a biological being, such as a cell, an organ, or a plant, is the period between genesis and death, during which some biological function is performed; this review will use long (or short) living in this case. In trees, it is quite common for a cell, such as a tracheid, to be still performing a useful function (in the case of a tracheid, in mechanical resistance and the conduction of sap) after it has undergone programmed cell death (PCD). It can be said that a tracheid is short-living but long-lasting after death, but its function as a living cell is not identical to that as a dead cell.

In technology, one important class of materials is called cellular materials (e.g. foams, honeycombs). These are made up of cells where physical matter is present only in the cell wall. The cavity can be filled with gas or liquid (or both). The cell is a basic component for mechanical engineering of such materials. Wood as a material belongs to this class. Plant organs are made up of cells in the same way, but the living cell is mainly a basic living unit of the plant.

In fibre-composite materials, another class of materials, the term 'fibre' is used to describe a portion of wire, usually made of stiff material, whose length is considerably greater than its diameter (10- to 100-fold). This can be glass fibre, carbon fibre, Kevlar fibre, but sometimes also natural fibres (e.g. flax and cotton). Plant fibres, such as tracheids or libriform fibres, are long thin cells whose geometry is similar to that of technological fibres. In pulp and paper technology, the term 'fibre' often refers to a group of cells adhering to each other. The plant cell wall is a fibre-composite according to the engineering definition. In this case, the term 'fibre' refers to the cellulose nanofibres, which are called microfibrils in plant anatomy.

\section{Muscle and motors}

'Muscle' is a term used to describe animal organs that are able to create forces. By analogy, this review will use 'muscle function' to describe this biological ability to create forces, and 'force generator' the living cells involved. In vertebrate animals, muscle action to control postire or create movement requires the presence of the skeleton, which can resist the muscles' forces. By analogy, in this review the inner, rigid part of a stem, where the tracheids, libriform fibres, and vessel elements are all dead cells, will be named 'skeleton', and passive wood resistance to forces will be named 'skeleton function'.
'Motor system' is a term commonly used in technology to describe a device that is able to produce motion or displacement. Antagonistic muscles acting on a joint is an example of a biological motor system. A bimetallic strip is a classic physical motor system: when the strip is heated, each metal undergoes different thermal expansion; this produces a tensile force on the side of the metal with lower expansion and a compression force on the other side, so there is a bending moment, and the curvature of the strip will grow in proportion to the dissymmetric expansion. The free end of the strip will move away to a distance nearly proportional to both the curvature change and the strip length.

\section{Force, torque, displacement, curvature, stress, and strain}

Usually, a tree does not move, but there are movements within a tree: a part of the tree, the tip of a branch, for example, can change position under the action of wind. This change of position of the top of a beam is named displacement $(\delta)$, measured in $\mathrm{m}$, and it is the result of a change in beam curvature (inverse of the curvature radius) $(\Delta C)$, measured in $\mathrm{m}^{-1}$. This change of curvature is the result of a bending moment (BM) acting on the beam according to the equation: $\Delta C=B M / E \times I$, where $E$ is the elastic modulus of the beam material and $I$ is the beam second moment of area (a purely geometric property). $E$ expressed in $\mathrm{Pa}\left[\left(\mathrm{kg} \times \mathrm{m} \mathrm{s}^{-2}\right) / \mathrm{m}^{2}\right]$ can be calculated from the density of wood $\left(D, \mathrm{~kg} \mathrm{~m}^{-3}\right)$ and the speed of sound propagation in wood $\left(S S, \mathrm{~m} \mathrm{~s}^{-1}\right)$, both of which are basic material properties, according to the equation: $E=D \times S S^{2} . S S^{2}\left(\mathrm{~m}^{2} \mathrm{~s}^{-2}\right)$ is termed the specific modulus.

In a solid, such as a tree, where the total of external forces (gravity force, soil reaction force, and force of wind) is zero, there are internal forces that differ from place to place, Stress is used for mechanical analysis of such forces. Stress has the same direction as an internal force and its amplitude $(\sigma)$ is the ratio between the force $(F$, expressed in $N)$ and the area of a small surface perpendicular to the force direction $(\Delta S): \sigma=F$ / $\Delta S$. Stress is measured in $\mathrm{Pa}\left(\mathrm{N} \mathrm{m}^{-2}\right)$, although $\mathrm{MPa}$ is more often used (a typical tyre pressure is $1 \mathrm{MPa}$ ).

Strain is a measure of relative deformation within a solid body. If the distance between particles was $l$ before deformation and $l+\Delta l$ after deformation, then the associated strain $(\alpha)$ is: $\alpha=\Delta l / l$. A strain is often the result of a stress action, but it can be linked to physical causes such as a change in relative humidity or temperature (i.e. hygroscopic shrinkage or thermal expansion). In simple unidirectional problems, for example, in elastic ropes, there is a simple proportional relationship between stress and strain: $\sigma=E \times \alpha$, where $E$ is the elastic modulus of the rope. In more general cases, the equation is the same but stress, strain, and elastic modulus are tensors.

\section{Residual stresses in 3D printing and assembly manufacturing}

Additive manufacturing, often called three-dimensional (3D) printing, is the term used to describe the process in which material is joined or solidified under computer control to create 
a 3D object, with matter (powder or liquid) being added together (Wong and Hernandez, 2012). In 3D printing, the material is created at the same time as the object. A new layer of material cannot contribute to the mechanical properties of the object before it has been deposited and solidified. Computeraided design is also used in the manufacture of objects by assembling material parts in order to make the final 3D object. In this case, material elements that are manufactured in separate processes before assembly, and each element can support loads when used.

There is a clear difference in the stress field within the two manufacturing methods for self weight loading. Imagine a column built classically by piling successive elements on to it vertically: until the desired height is reached, there will be a uniform compressive stress field $\sigma_{0}$ all over the base element (Fig. 1A). If 3D printing is used to create the same column, each new material layer starts to be loaded only after it has solidified. From the moment that it has been produced at a distance $r$ from the centre, until the final building of the column, the material layer situated at position $r$ will support an increase of compressive stress due to the deposition of each new layer. So the final stress will be highest near the centre (the first deposited layer will support all the successive increases of compressive stress due to successive deposition). The last deposited layer, being just solidified, will not support any stress from what has happened before (Fig. 1B), so residual stress at the periphery will be zero. There is also a large difference in the gravity stress field for a horizontal beam that was previously manufactured as a piece of material and then attached to a wall, and a similar beam produced layer by layer in a 3D printing operation (Fig. 2).

\section{Tree growth is a kind of 3D printing}

The manufacture of the woody compartment of the tree (i.e. the trunk and branches) consists of a layer-by-layer deposition of new matter. This kind of 3D printing is known as growth, and results in geometrical change of the tree structure characterized by apical elongation (Barthélémy and Caraglio, 2007) and increase in the diameters of woody axes. Growth is a two-step process (Plomion et al., 2001): (i) mother cell division, defining the number of new cells in longitudinal and transverse directions, and (ii) daughter cell differentiation and expansion,

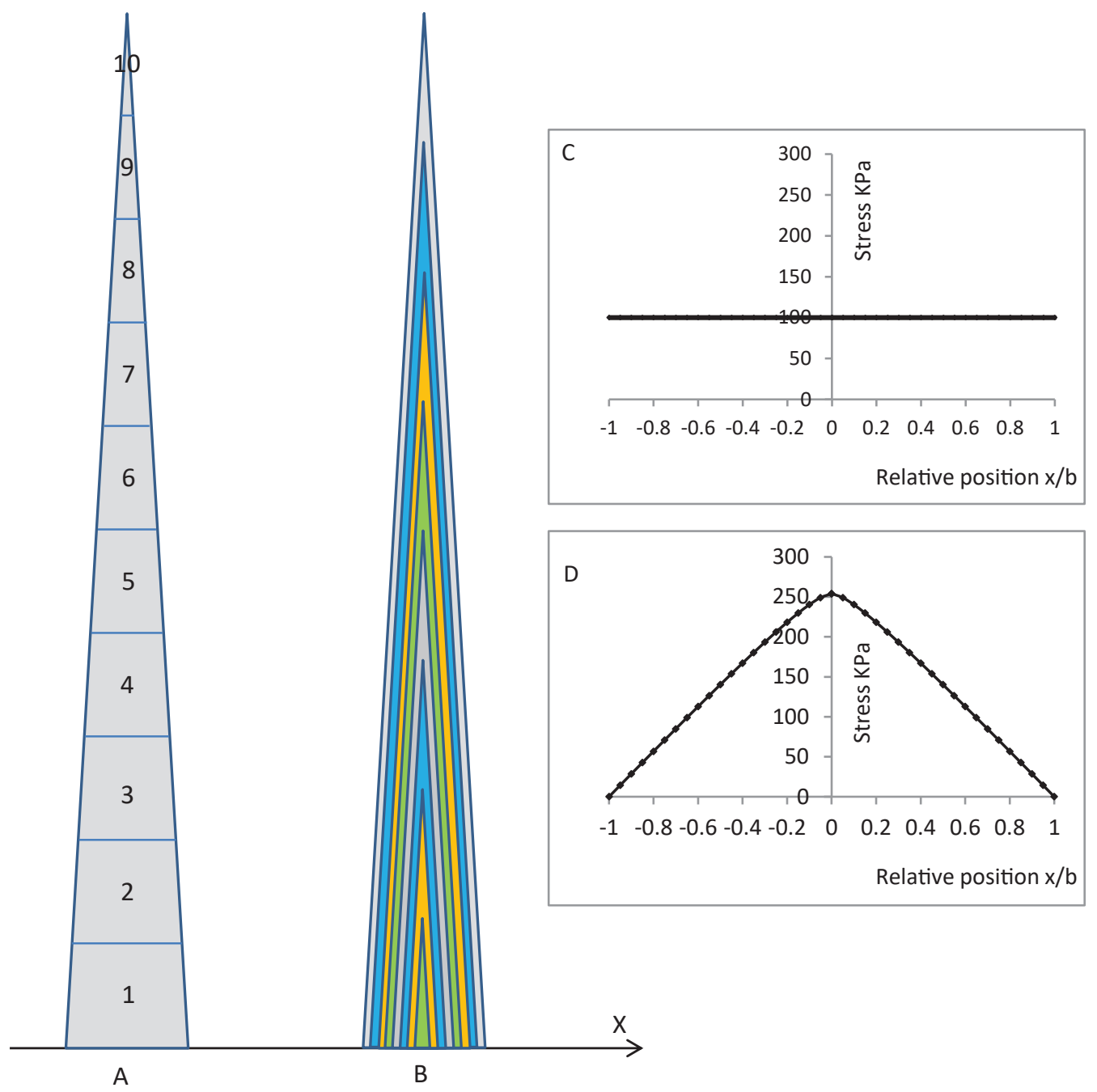

Fig. 1. Stress field due to gravity at the base level of a vertical conical beam. (A) Stacked layer construction. (B) 3D printing-type construction. (C) Stress distribution for the beam in A, built by piling 10 successive parts.(D) Stress distribution for the beam in B, built using 3D-type manufacturing. Simulation for a 50:1 ratio between height and basal diameter (2xb) at each step. Total height $30 \mathrm{~m}$; basal diameter $60 \mathrm{~cm}$; material density $1000 \mathrm{~kg} \mathrm{~m}{ }^{-3}$. 


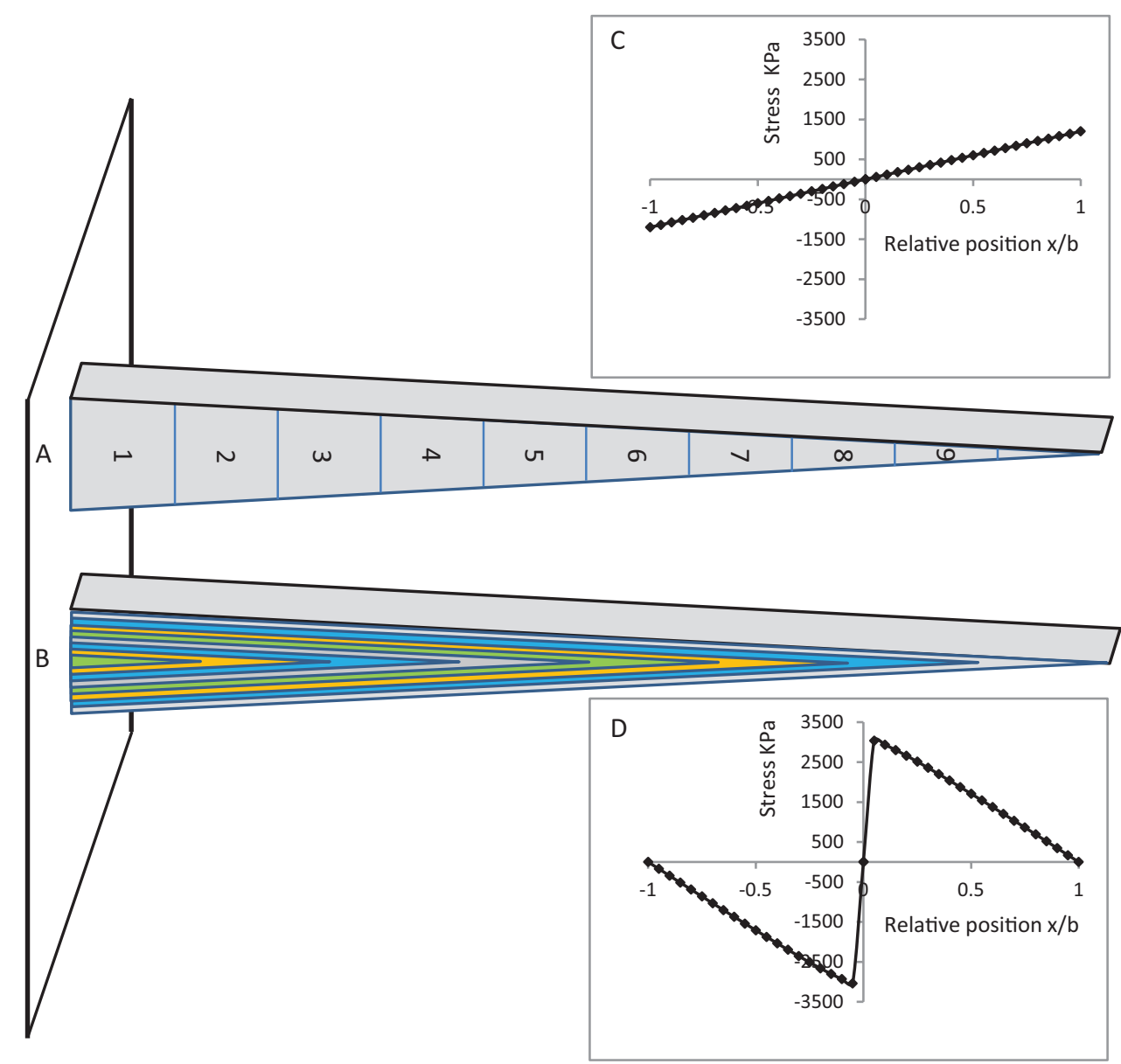

Fig. 2. Stress field on the section of a horizontal beam at anchorage level due to gravity. (A) Stacked layer construction. (B) 3D printing-type construction. (C) Stress distribution for the beam in A, built by piling 10 successive parts. (D) Stress distribution for the beam in B, built using 3D-type manufacturing. Simulation for a 10:1 ratio between length and basal height $(2 \times b)$ at each step. Total length $6 \mathrm{~m}$, basal beam height $60 \mathrm{~cm}$, constant beam width $10 \mathrm{~cm}$; material density $1000 \mathrm{~kg} \mathrm{~m}^{-3}$.

defining the proportion and dimensions of the different types of wood cells. Each step of growth is defined by two main parameters: the increase in length of the axis $(\delta H)$ and the increase in radius (distance from the pith) at a given position $(\delta R)$. The axis can be straight or sinuous. The transverse section can be circular or more or less elliptical, or sometimes profiled like a $\mathrm{T}$ or $\mathrm{H}$ beam (with a more complex pattern on section) (Fig. 3).

\section{The evidence for a muscular action of living wood}

If there is only gravitational force acting during growth, the peripheral residual stress at any height should be zero (Figs 1 and 2). A classical way to measure in situ stresses inside a structural element is to measure the consequences of these stresses in term of strains, using strain gauges or strain transducers attached to the stressed material by using glue, nails, or screws (Yang et al., 2005). (The local strain $\varepsilon$ is proportional to the local stress $\sigma$ according to the equation $\sigma=E \times \varepsilon$, where $E$ is the modulus of elasticity of the material.) By cutting grooves on both sides of the strain gauge (Yoshida and Okuyama, 2002 Jullien and Gril, 2008) or boring a hole between the sensor tips (Fournier et al., 2014), there will be a suppression of the local stress, inducing a measured strain opposite to the strain that was present before machining (Fig. 4). These two methods have been largely used on living trees in order to measure longitudinal (and sometimes also tangential) strains at the periphery of trees or branches (Fournier et al., 1994b;Yoshida and Okuyama, 2002). In a very large majority of cases, the measured strain indicated that there were strong tensile stresses at the trunk periphery.

Kübler (1959a, b, 1987), Archer (1986), and Fournier et al. (1991a, b) produced a convincing explanation and models that are universally accepted today. The origin of pre-stressing inside a stem comes from the process of maturation of the cell wall until the end of lignification, which should lead to small strains (both longitudinal and tangential) of the cell wall if it was free: these are termed maturation strains. Because the new layer of living wood is 'glued' to the rigid wood skeleton, this deformation is blocked, inducing constraint forces in the new lignified layer. If $\alpha_{\mathrm{m}}$ is the maturation strain, $\mathrm{E}$ is the elastic modulus, and $\Delta S$ is the surface area of the new lignified layer, 


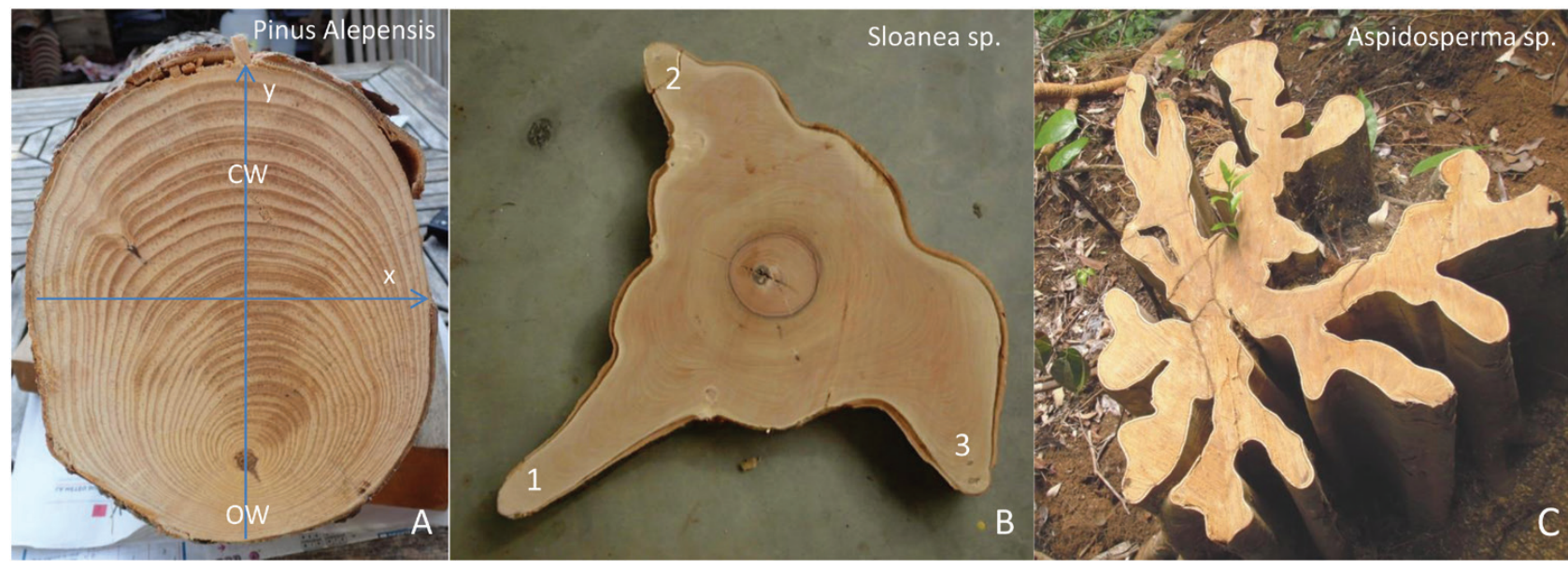

Fig. 3. Examples of non-isotropic radial growth at the stem or branch. (A) Dissymmetric growth with compression wood (CW) and opposite wood (OW) on the long ray in the $y$ direction. The planar second moment of area of the branch section is $20 \%$ higher for the $x$ axis. (B) Occurrence of buttresses (numbered 1-3). The lever arm is much higher for the buttress extensions, and direction 1 is opposite to the direction in which the trunk is leaning. (C) Complex profile of a section with a better stiffness in bending for a given matter content, as compared with a circular section.

the force needed to prevent the maturation strain (the same as producing the opposite of this strain) will be $F_{\mathrm{m}}=-\alpha_{\mathrm{m}} \times E \times \Delta S$, where $F_{\mathrm{m}}$ is the maturation force and $\sigma_{\mathrm{m}}=-\alpha_{\mathrm{m}} \times E$ is the maturation stress occurring in the last lignified layer. If $\alpha_{\mathrm{m}}$ is a contraction, the generated force will be a tension; conversely, if $\alpha_{\mathrm{m}}$ is an expansion, the generated force will be a compression. This force is applied to the rigid skeleton and there should be a reaction force exactly opposite to $F_{\mathrm{m}}$ in the whole section of the skeleton. This induces a small uniform decrease of residual stress on the whole section according to the equation $\Delta \sigma=-F_{\mathrm{m}} / S$, where $S$ is the surface area of the skeleton section. For each new lignified wood layer, the residual stress of the older lignified layers will decrease step by step, leading to a typical stress field called a maturation stress field.

The total residual stress field inside the skeleton, at the base for example, is just the sum of gravity (compression and flexure) and maturation stress fields (Fig. 5). Usually, the longitudinal strain measured in situ is an elongation exactly opposite to the active contraction of the last formed fibres. In the tangential direction an active expansion is measured corresponding to a compressive stress in that direction (Clair et al. 2013). The resulting pre-stressing field, for standard vertical stems, is very similar to the maturation stress field (the gravity stress field is negligible) predicted by the models cited above: (i) a longitudinal tensile stress at the periphery compensated for by a very large compressive stress in the core, (ii) a compressive tangential stress at the periphery compensated for by a very large tensile stress in the core, and (iii) zero radial stress at the periphery and also a large tensile stress in the core.

This stress field depends only on the number of successive layers, that is, the diameter of the section, for a constant maturation force of the layer. The residual stresses (and the stored elastic energy) in the core of the trunk will grow with the diameter until they reach very high levels, either in longitudinal compression or in radial and tangential tension. This is the cause of end splitting of logs when they are cross cut and may be a cause of compressive failures, ring shakes, or heart shakes that sometimes appears in the core of living trees (brittle heart). Moreover, the mechanical function of the core is very limited, and brittle heart as a possible negative effect has been maintained through evolution.

During a large measurement campaign (Jullien et al., 2013) of 440 European beech trees (eight strain measurements per tree), whose mean diameter and total height were respectively $60 \mathrm{~cm}$ and $33 \mathrm{~m}$, the mean active contraction was $800 \mu \mathrm{def}$ $\left(1 \mu \mathrm{def}\right.$ represents $\left.1 \mu \mathrm{m} \mathrm{m}^{-1}\right)$. The range of maturation strains was very large (Fig. 6), from zero to $>3500 \mu$ def.

Knowing the elastic modulus of the woody tissue enables calculation of the mean tensile stress (10 MPa in the case of beech described above). The uniform compressive stress of the whole mass of the tree ( 10 tons) on the base of the trunk should have been only $0.3 \mathrm{MPa}, 30$ times less than the maturation stress.

\section{The living wood}

Wood is made of three main cell types (Raven et al., 2007; Wiedenhoeft, 2010). Stem cells are located on the entire margin of woody parts: at the tip for elongating woody axes (primary meristems) and in cylindrical sleeves around these axes, just below the bark, for thickening of woody axes (cambium). These cells are active throughout the tree's life and keep dividing into daughter cells.

Parenchyma cells are long-living (often for many years) multifunctional cells: they have roles in sap flow regulation, chemical synthesis for resistance to microorganisms, storage of nutrients, resin, or minerals, and the replacement of stem cells. Their global PCD corresponds to the formation of heartwood, in which there are no living cells remaining in the wood.

Tracheids, libriform fibres, and vessel elements are shortlived cells (up to a few months) but are long-lasting once dead (often for more than 100 years) (Courtois-Moreau et al., 2009; Cuny et al., 2012; Cuny, 2013); their functions, for both living and dead cells, are purely mechanical, comprising both structural and hydraulic roles. Gymnosperms (conifers) have only 

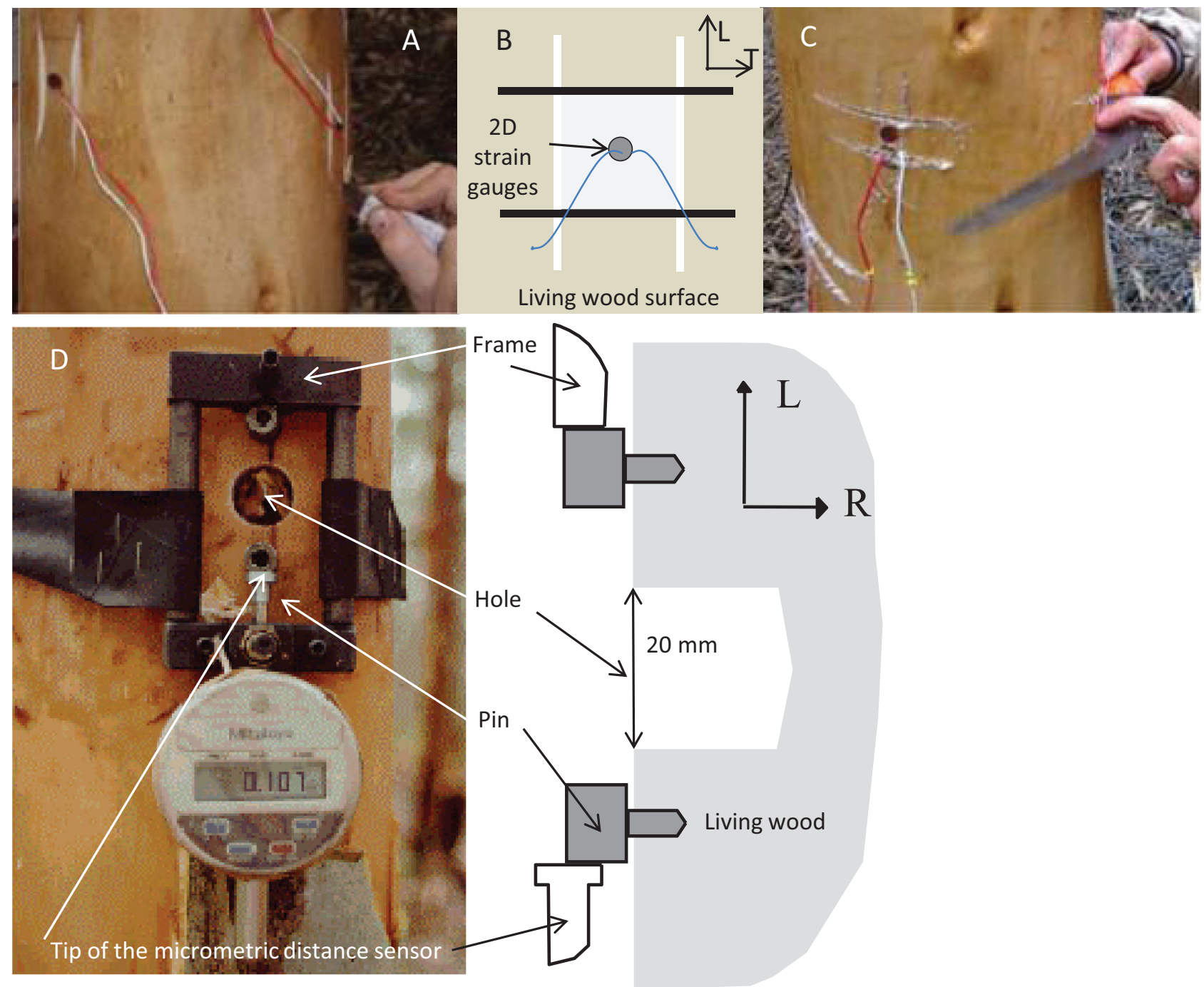

Fig. 4. In situ measurements of 'muscle' strain in living wood. (A-C) Measurement of tangential and longitudinal strain using the two-grooves method. A two-dimensional strain gauge is glued on the surface of the living wood, and strain is measured by an electrical device. (A) Longitudinal grooves are cut first to facilitate measurement of tangential strain (Photo courtesy of Bruno Clair). (B) Schematic diagram of two-grooves strain measurement in both directions. (C) Tangential grooves are cut afterwards, to allow measurement of longitudinal strain. (D) Measurement of longitudinal strain using the single-hole method (Photo courtesy of Caroline Loup). Two pins are nailed into the living wood, supporting a micrometric distance sensor whose tip is pressed again the lower pin, with the sensor zeroed. A hole is manually drilled between the pins and the variation in distance between the pins, termed growth strain indicator (GSI), is indicated in $\mu \mathrm{m}$ on the dial. The longitudinal maturation strain at the trunk periphery is proportional to GSI according to the equation: $\alpha_{1}=12.9 \times \mathrm{GSI} ; \alpha_{1}$ in $\mu$ def $\left(10^{-6}\right)$, GSI in $\mu \mathrm{m}$ (the relationship is species dependent; this example is for beech).

tracheids, while all three of these cell types can be present in angiosperms. Living tracheids play an active mechanical role, while dead tracheids play both a passive structural and a hydraulic role (in the ascent of sap).Vessel elements do not play an important mechanical role, but dead vessel elements plays a hydraulic role. Libriform fibres successively play an active and a passive mechanical role (Cruiziat et al., 2002). PCD of vessel elements is rapid (2 weeks) while that of tracheids or libriform fibres is slower (1-4 months), (Courtois-Moreau et al., 2009; Čufar et al., 2011; Cuny, 2013; Cuny et al., 2014).

There are three successive zones in a section of a woody axis, from bark to pith (Fig. 7): (i) the whole living cells zone, which can be subdivided into three successive zones-the division zone or cambial zone, the expansion zone, and the lignification zone (Lz); (ii) the living parenchyma zone, in which all other cells are described as mature (in fact, they are dead); and (iii) the heartwood zone, where all cells are dead.

A temporal description can also be used for the succession of periods concerning an individual tracheid: (i) the birth of a new tracheid dates from cell division in the cambium; (ii) the expansion phase lasts until the final geometry is reached ( $\sim 1$ month); (iii) the maturation phase lasts until PCD and full lignification (some months); and (iv) the dead mature phase then lasts as long as the stem persists (up to many years), with chemical modification by the addition of extractives during heartwood formation. As time goes on, a particular tracheid will be further and further away from the cambium. 


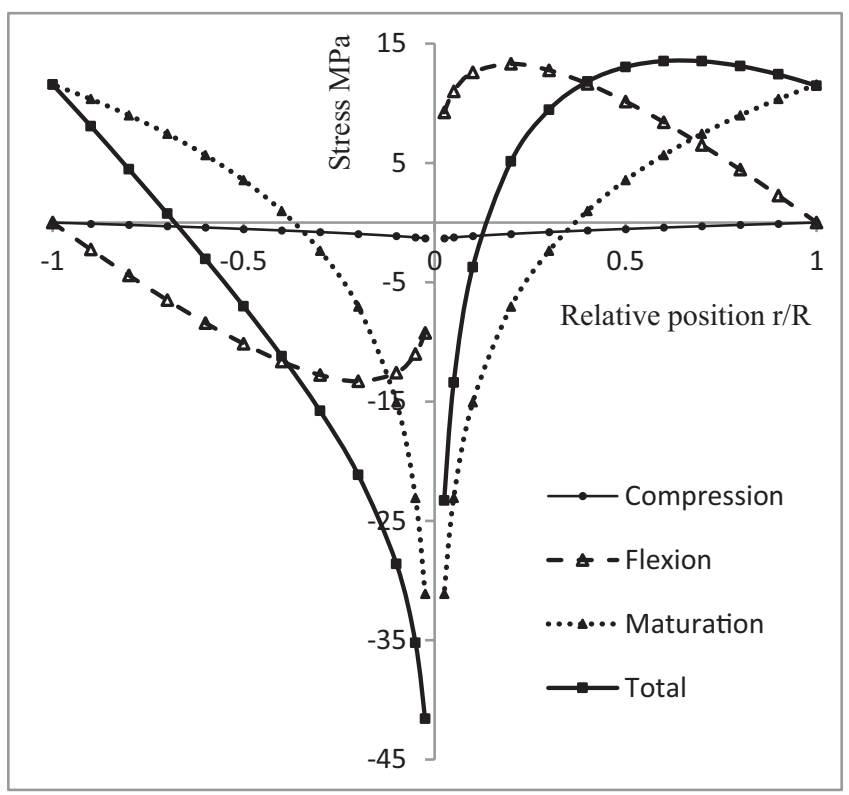

Fig. 5. Gravity stress, maturation stress, and total growth stress fields for an inclined tree, Support: gravity flexure stress at the stem base. Maturation: maturation stress, homogeneous value (12 MPa) all around the section Total support + Maturation: growth stress at the stem base. Calculations are made using the model described in Alméras et al. (2018) with the following parameters: allometric exponent between radius and length 2/3; basal diameter $50 \mathrm{~cm}$; total height $30 \mathrm{~m}$; wood density $840 \mathrm{~kg}$ $\mathrm{m}^{-3}$; maturation stress $12 \mathrm{MPa}$.

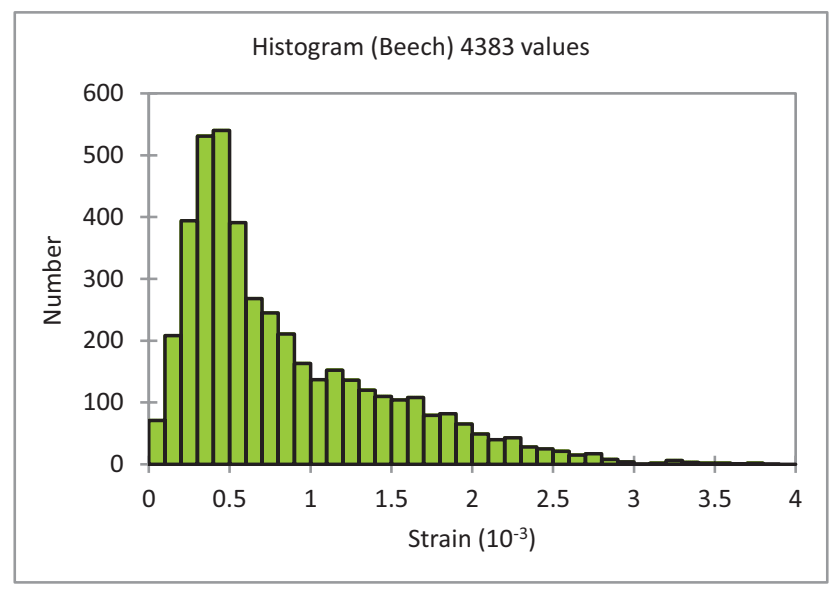

Fig. 6. Histogram of maturation strain values measured in 440 adult beech trees. Eight equidistant measurements were made per tree. $\mu$ def, $\mu \mathrm{m} \mathrm{m} \mathrm{m}^{-1}$ or $10^{-6} ; 3000 \mu \mathrm{def}=0.3 \%$.

\section{Posture control and movement within a tree}

A second important finding of in situ measurement of maturation strains is that most trees have a dissymmetric distribution of values around the periphery of the trunk (Fig. 8), with high values (mean for beech $19 \mathrm{MPa}$ ) on one side and low values (mean $4 \mathrm{MPa}$ ) on the opposite side (Becker and Beimgraben, 2001; Jullien et al., 2013). This resembles some types of motor system, like a bimetallic strip or antagonistic muscles, producing an active rotating torque on the stem or branch (Coutand et al., 2007; Alméras and Clair, 2016).

One difference between the mechanics of tree parts and a mechanical device is the coexistence, in every step, of additive manufacturing and force generation. Specific incremental models are required in order to calculate the result of the competition between torque changes due to gravity (growth) and dissymmetric maturation strains. There have been many theoretical and experimental studies on this subject, assuming more and more complex situations (Sinnott, 1952; Fournier et al., 1994a; Huang et al., 2005; 2010; Moulia et al., 2006; Coutand et al.; 2007; Moulia and Fournier, 2009; Alméras and Fournier, 2009; Alméras et al., 2005a, 2009; 2018). Successive papers from Alméras et al. (2005a, 2009, 2018) give a good review of the basic results. For oblique growth of a trunk or branch the posture (i.e. the angle of oblique growth) cannot be maintained, whatever the inclination. Without an active bending moment due to maturation forces the inclination will grow with each new growth addition. Second, in order to maintain a constant angle of oblique growth, the active bending moment should compensate for the growth of the bending moment resulting from the growth step. Third, in order to restore the verticality of an oblique axis, for example, after an accident (as described below), the active bending moment should be much higher than the growth of bending moment resulting from the growth step. Fourth, the difference in maturation strain between the two faces of the inclined axis is the motor for posture control and top axis movement.

\section{Normal and special maturation forces}

In early studies, wood scientists found that the wood produced on the upper part (in angiosperms) or the lower part (in gymnosperms) of a large horizontal branch was notably different from the rest of the wood of that branch (Onaka, 1949; Sinnott, 1952; Dadswell and Wardrop, 1955; Fisher and Stevenson, 1981). This type of wood is termed reaction wood; it is subdivided into tension wood (on the upper part of the branch) and compression wood (on the lower part) (Wilson and Archer, 1977; Timell, 1986; Gardiner et al., 2014). Tension wood and compression wood differ from normal wood in terms of both the microstructure and the chemical composition of the fibre or tracheid wall (Côté et al., 1969; Tanaka et al., 1981; Ruelle et al., 2006, 2007; Fang et al., 2008; Sultana et al., 2010). Tension wood has a lower proportion of lignin than normal wood, while in compression wood the proportion of lignin is higher; crystalline cellulose nanofibres are nearly parallel to the fibre direction in tension wood, while in compression wood they make an angle between $30^{\circ}$ and $50^{\circ}$; and both types have significant changes in the composition of hemicelluloses or lignin monomers (Baillères et al., 1995). In situ measurements (Yoshida et al., 2000; Alméras et al., 2005b; Clair et al., 2006) show that the tension wood on the upper part of angiosperm branches produces very high tensile forces (often three times the mean value), while compression wood on the lower part of gymnosperm branches produces 

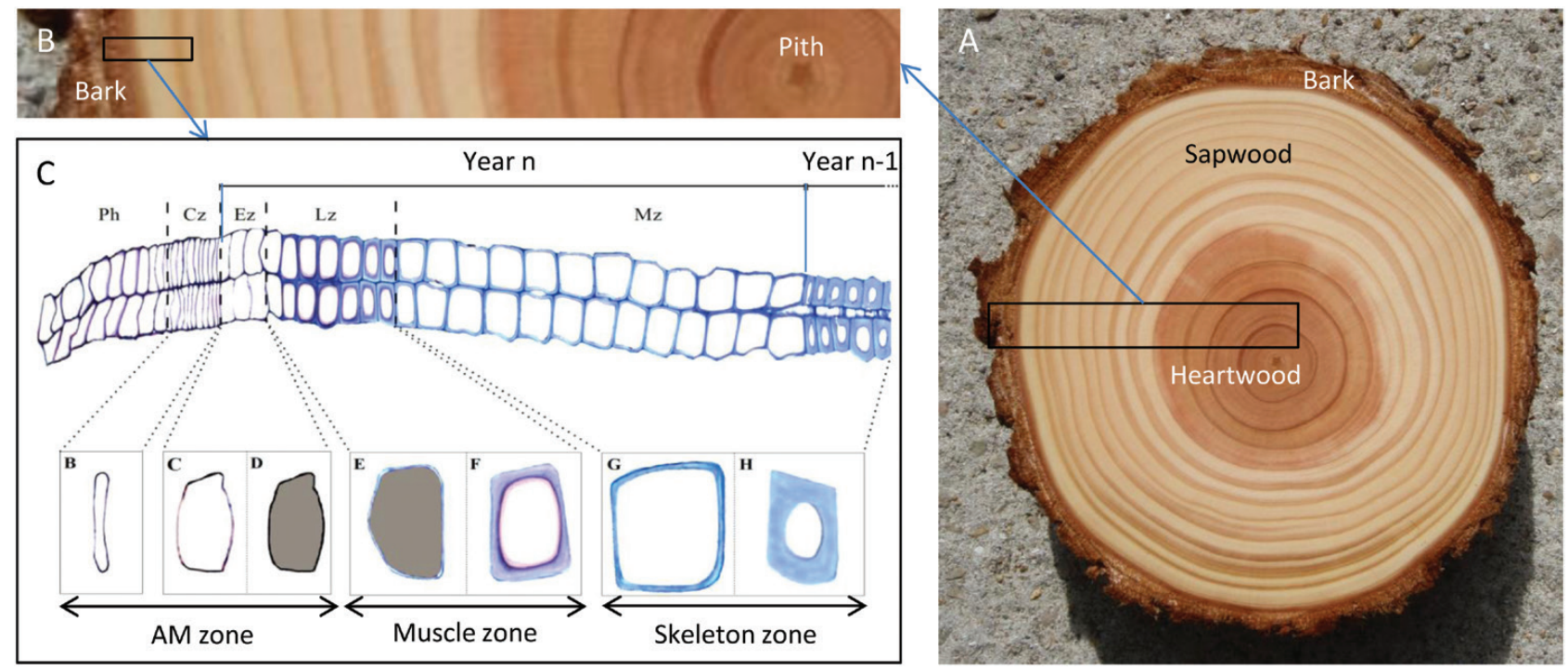

Fig. 7. Different functional zones of the living wood in a gymnosperm. (A) Transverse section of a trunk. Heartwood is dead wood and sapwood is the living wood. (B) Successive growth rings from pith to bark. Each growth ring is the result of 1 year of additive manufacturing. (C) Diagram showing detail of the two most recent growth rings (adapted from Cuny, 2013). Ph, phloem (which is part of the bark). Cz + Ez, additive zone, including cell division (Cz) and cell expansion (Ez); this is the zone of additive manufacturing where geometric growth takes place. Lz, lignification zone; this is the 'muscle zone' where the tracheids are still living and their cell walls are thickening. Mz, mature xylem zone; this is the 'skeleton' zone, where the tracheids are dead and perform both passive hydraulic conduction and mechanical resistance roles.

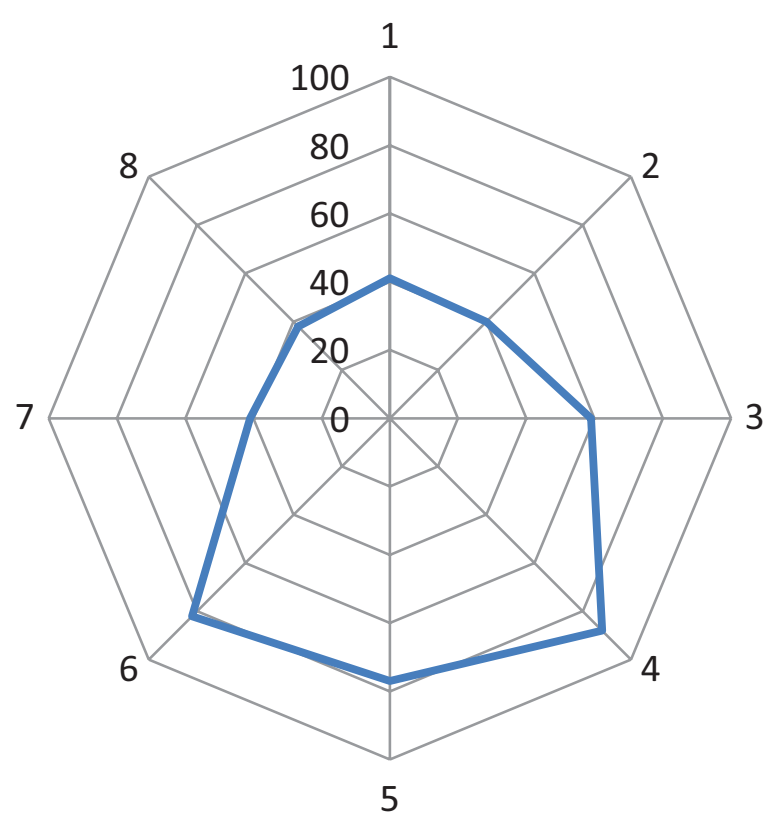

Fig. 8. Example of dissymmetric distribution of GSI values in relation to eight cardinal points for a mature beech (tree F33 from the FAIR-project CT 98-3606, without tension wood). Numbers along the direction 1 are GSI values (see Fig. 4D). Positions 1-8 correspond to the eight equidistant locations on the trunk periphery where the holes were drilled.

high compressive forces (sometimes twice the mean value in absolute terms). Here, these forces will be termed special maturation forces.

Since the beginning of the 1990s many experimental studies have been performed on small trees (both angiosperms and gymnosperms) artificially inclined at angles varying from $10^{\circ}$ to $45^{\circ}$ (Yoshida et al., 2000; Jourez et al., 2001; Thibaut et al.,
2001; Coutand et al., 2007) (Fig. 9). Regardless of the species, there was a clear tendency for trees to restore the vertical posture in the quickest way possible (Alméras et al., 2009). In each case, a large sector of reaction wood was involved in order to maximize the bending moment. The typical geometry of vertical restoration was often seen on trees whose diameter was up to $30 \mathrm{~cm}$, mostly in zones of soil instability. They were studied as field examples of the same experiment (Alméras et al., 2005b; Clair et al., 2006; Ruelle et al., 2007). It was shown that the upper or lower face of the branches of the tree restoring verticality both have typical tension or compression wood and in situ maturation strain values (Fig. 10) corresponding to special maturation forces.

Normal wood refers to wood with a standard chemical composition of the main cell wall polymers, with only small variations around the mean values ( $10 \%$ for all components); the differences in composition for some basic components, such as lignin, cellulose, and hemicelluloses, are much higher between reaction wood and normal wood (Yeh et al., 2005, 2006; Brennan et al., 2012; Fagerstedt et al., 2014). Juvenile wood, mature wood, opposite wood, lateral wood, flexure wood, are resonant wood are all types of normal wood. The main basic variation within normal wood is in the angle between crystalline cellulose nanofibres and the fibre (or tracheid) direction [the microfibril angle (MFA)]. This can vary between $\sim 5^{\circ}$ (in spruce resonant wood) to $40^{\circ}$ (in internal spruce juvenile wood), with values of $\sim 15^{\circ}$ being the most common. In the wide range of MFA values, the living fibres or tracheids are able to produce normal maturation strain in a wide range that falls within the values of maturation strain in reaction wood (Alméras et al., 2005b).

It should be noted that phloem, which is produced by the same cambium and consists of the same cell types, including 

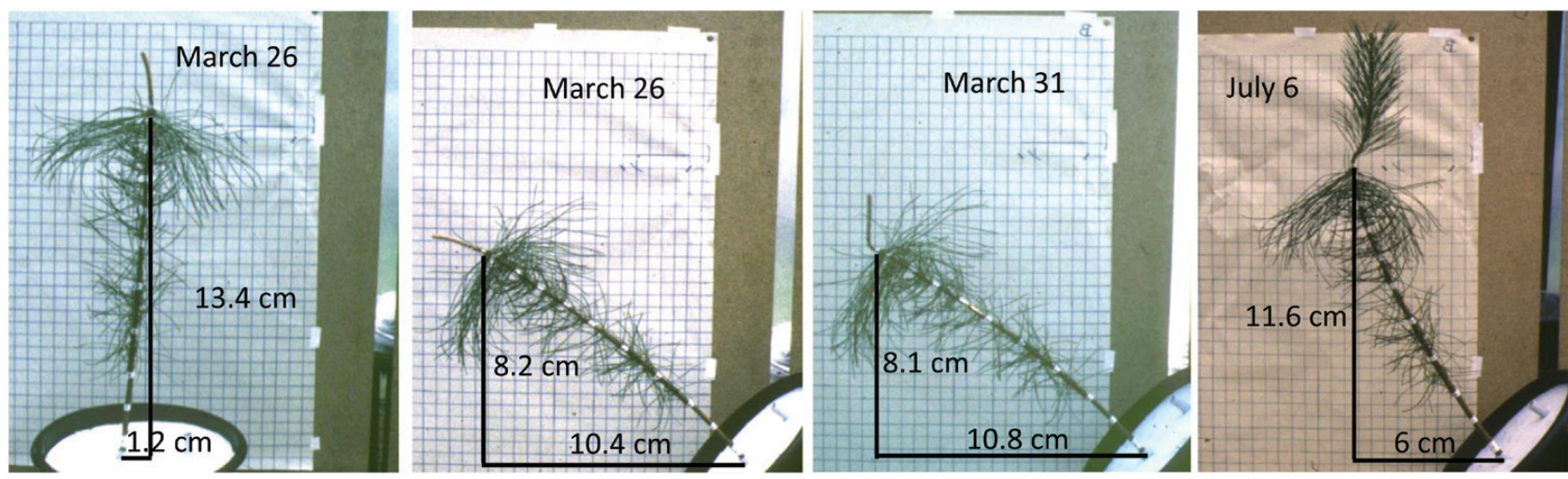

Fig. 9. Artificial bending of a young pine. On March 26 , the sapling is inclined at $45^{\circ}$. There is an immediate downward curvature of both the lignified trunk and the non-lignified tip. On March 31, after only a few days, the tip has restored its verticality (owing to turgor pressure dissymmetry) while the downward curvature of the trunk has increased a little (owing to the viscoelastic behavior of green wood). On July 6 , after 3.5 months, there is both primary and secondary growth. The old trunk (former lignified wood) has changed to an upward curvature in order to restore verticality (dissymmetry of muscle action). The lower part of the height increment is lignified and trying to restore its verticality because of the straightening of the old trunk. The tip keeps growing vertically.

fibres, performs very similar functions to those of xylem. The muscle function of phloem seems to be of utmost importance for stems with very small diameters (Gorshkova et al., 2018).

\section{Libriform fibre or tracheid structure and the mechanical behaviour of wood}

The stiffness and strength of wood are mostly due to tracheids and libriform fibres. The mechanical role of a tracheid (things are very similar for libriform fibres) will change from an active role while the tracheid is living to a passive role when it is dead. During the expansion phase, the living tracheid has an active function of increasing the length and diameter of the stem geometry and its mass (mostly liquid mass); this is a type of additive function, like in 3D printing. During the lignification phase there is no further change in volume but a strong increase in the dry mass and a very large increase in the modulus of elasticity and the active generation of maturation forces-that is, in the muscle function. During the mature (dead) phase there is no further change in the geometry, dry mass, or modulus of elasticity, but there is a progressive increase or decrease in residual stress, depending on the specific conditions. Tracheids are mostly involved in passive mechanical resistance to external forces- that is, in the skeleton function.

The cell wall thickening that is the beginning of secondary wall deposition arises at the end of the cell expansion phase (Abe et al., 1997). Successive layers of fibre composite material are deposited inside the cell lumen, adherent to the primary wall (Mellerowicz et al., 2001; Fahlén and Salmén, 2002; Harrington, 2002; Burgert, 2006; Gibson, 2012). At the end of this process there is a thick secondary wall surrounding a cavity (lumen) filled with fluid. A description of the cellular level in the three reference planes-tangential/radial, radial/longitudinal, and tangential/longitudinal-is available in anatomy texts (e.g. Wheeler and Baas, 1998). Porosity (cell and lumen diameter) and fibre orientation (straight, spiral, or interlocked) are key parameters for both hydraulics (lumen diameter is key for sap conduction) and structural mechanics (fibre anisotropy).

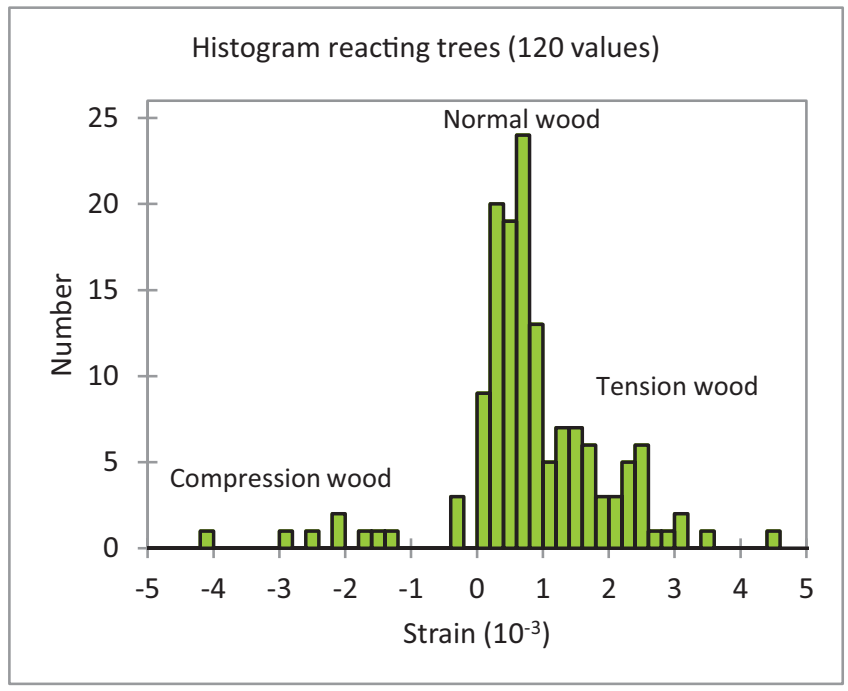

Fig. 10. Histogram of maturation strain values measured in 16 young trees undergoing a clear process of vertical restoration. Diameter at breast height was $\sim 30 \mathrm{~cm}$. Trees comprised 11 tropical species (from 11 different families, with basic densities ranging from 290 to $780 \mathrm{~kg} \mathrm{~m}^{-3}$ ) and three gymnosperms (three different species in the Pinaceae family).

There is very little variation in the cell wall density (Kellogg and Wangaard, 1969). Thus, wood density is directly related to the ratio of cell diameter to cell wall thickness, which is known to be the main driver for the properties of cellular material (Gibson and Ashby, 1997; Kretschmann, 2010). However, wood density also depends on moisture content (Glass and Zelinka, 2010), that is, the sum of water molecules inserted inside the hydrophilic cell wall polymers and of 'free' water present inside the cell lumens in association with gas Dlouhá et al., 2018). For wood as an engineering material, the reference is the density at $12 \%$ moisture content $\left(\mathrm{D}_{12}\right)$. Biologists prefer to refer to basic density $(\mathrm{BD})$, which is the ratio of anhydrous mass to green volume, two measures that are independent of the free water content of the green wood. A proportional relationship can be defined between these two density parameters: $\mathrm{BD}=0.828 \times \mathrm{D}_{12}$ 
(Vieilledent et al., 2018), with fairly good precision for all species.

The ultrastructure of the cell wall, describing the multilayered fibre composite wall material, is the domain of nanostructure and chemistry. Schematically, the nanofibres are made of crystalline cellulose, while the matrix is a mixture of polysaccharides (hemicelluloses) and polyphenolic (lignin) polymers. The density of the cell wall is almost constant among species $\left(1500 \mathrm{~kg} \mathrm{~m}^{-3}\right)$ and is thus not a pertinent parameter. Key parameters for mechanical behaviour are the crystalline cellulose content, the MFA, and the chemical composition of the matrix (Cave, 1969; Harrington et al., 1998; Donaldson, 2008; Mellerowicz and Sundberg, 2008; Salmén et al., 2012)

The parameters of cellulose are directly linked to the specific modulus (SM). For dry wood (12\% moisture content), $\mathrm{SM}_{12}$ (in $\mathrm{m}^{2} \mathrm{~s}^{-2}$ ) is the square of the speed of sound in the direction of the fibre. For green wood, it is possible to define a basic specific modulus (BSM), which is the ratio of the elastic modulus in the fibre direction of green wood (this does not depend on the moisture content of green wood) and its basic density. Again, a proportional relationship can be defined between these two parameters: $\mathrm{BSM}=0.86 \times \mathrm{SM}_{12}$, with a fairly good precision for all species (Glass and Zelinka, 2010). There is no correlation between specific modulus (or B SM) and density (or BD) as determined in a large number of trees (2234) and species (601) (Dlouhá et al., 2018), and the two descriptors of wood maturation can be viewed as independent.

\section{Wood structure and force generation}

The maturation force created by a wood layer portion at the end of its life can be calculated using the formula: $F_{\mathrm{m}}=A_{\mathrm{w}} \times \alpha_{\mathrm{m}} \times$ $\mathrm{BSM} \times \mathrm{BD}$, where $A_{\mathrm{w}}$ is the section area of the wood layer portion, resulting from both cell division and the expansion phase, $\alpha_{\mathrm{m}}$ is the maturation strain (using a positive sign for contraction, which is the more usual case), resulting from the lignification phase, BSM is the basic specific modulus, representative of cell wall mechanical stiffness, mainly the result of cellulose microfibril deposition (Cave, 1969;Donaldson, 2008), and BD is the basic density, representative of the ratio between cell wall volume and total wood volume.

The very wide range of maturation strain $\left(\varepsilon_{\mathrm{m}}\right)$ measured in situ in living trees (Figs 6 and 10) is not yet understood. Boyd $(1950,1972)$ suggests that the driver of maturation strain is a swelling of lignin during its deposition. The variations in cellulose MFA explain the variations in maturation strain. Bamber (2001), looking at tension wood, suggested that there is a shrinkage in cellulose bundles (the cellulose tension theory). Okuyama et al. (1994) propose a 'unified theory' where there is both lignin swelling and cellulose shrinkage.

The simplest Boyd model based on MFA changes is quite good for normal wood in which MFA varies between $5^{\circ}$ and $40^{\circ}$. The Bamber model, revisited in recent studies on tension wood (Clair et al., 2011; Gorshkova et al., 2012, 2018; Mellerowicz and Gorshkova, 2012; Alméras and Clair, 2016), seems useful for tension wood, where MFA is always small. For compression wood, there is a strong difference in the matrix chemical composition, and models predicting acoustic damping (Brémaud et al., 2013) or shrinkage (Leonardon et al., 2010) should take this chemical difference into account. A form of Boyd model incorporating a much higher lignin swelling could also work.

In summary, it can be said that maturation strain in normal wood is mostly linked to large variations in MFA, while in reaction wood the drastic changes in chemical composition are the key.

\section{Relative influence of geometry, material, and force generation in tree biomechanics}

In a review paper, Fournier et al. (2013) suggest four biomechanical traits based on parameters of both stem geometry and wood properties. The first trait is safety against winds $(\mathrm{SW}): \mathrm{SW}=K_{\mathrm{w}} \times\left(\sigma_{\mathrm{c}}\right) \times D^{3} / H$, where $K_{\mathrm{w}}$ is a parameter linked to the crown structure and its interaction with wind as well as stem form. The second trait is safety against buckling (SB): $\mathrm{SB}=K_{\mathrm{b}} \times\left(E / \rho_{\mathrm{t}}\right)^{0.25} \times D^{0.5} / H^{0.75}$, where $K_{\mathrm{b}}$ is a parameter linked to gravity and stem form. The third trait is motion velocity (MV): $\mathrm{MV}=K_{\mathrm{m}} \times \delta D \times \delta \alpha / D^{2}$, where $K_{\mathrm{m}}$ is a parameter linked to section geometry and mostly to dissymmetry of both growth and modulus of elasticity between upper and lower part of the axis (see Alméras et al., 2005b). It is an indicator of the radial growth needed to achieve a change in. Radial growth is a proxy of time, and MV is an indirect measure of the speed of restoration of verticality. The fourth trait is performance of posture control $(\mathrm{PC}): \mathrm{PC}=K_{\mathrm{p}} \times \delta \alpha \times\left(E / \rho_{\mathrm{t}}\right) /[(H / D) \times(H \times \sin \phi)]$, where $K_{\mathrm{p}}$ is a parameter linked to gravity and stem form.

Geometrical parameters are the total length (or height) $(H)$ and diameter $(D)$ of the stem, their ratio $H / D$ (i.e. slenderness), $\delta D$ (diameter increment), and $\phi$ (angle from the vertical of the stem or branch). The wood material parameters are the density, modulus of elasticity, specific modulus, and rupture strength in compression. Force generation parameters are $\alpha_{\mathrm{m}}$ and $\delta \alpha_{m}$ (dissymmetry of maturation strain between the upper and lower part of the stem) combined with radial growth and wood material parameters.

It should be noted that the geometrical parameters are the most important in the passive mechanical resistance of the skeleton. Motion velocity and posture control traits show that none of these functions could be accomplished without a dissymmetry in force generation between the upper and lower parts of the stem or branch.

\section{Modulation of living wood hydraulics and mechanical answers to common problems}

The two main external constraints during a tree's life are water availability and light access. The ascent of sap is mostly passive in the sapwood skeleton, except for its regulation by the parenchyma cells (Beeckman, 2016). The frequency of the conduits, lumen diameter, perforations, and pits are the main parameters of the geometry of the 'pipe' system. So, regulation in terms of the distribution of conduits and their diameter and connections 
should be prepared by cambial activity (i.e. cell division and expansion) in advance of water stresses. A classical form of modulation is spring/summer or wet/dry seasonal variations in water stress leading to greater porosity of the conducting system during wet periods (Fonti et al., 2010; Björklund et al., 2017).

Light access is a strong driver of growth adaption. Vertical growth is the norm for stems with isotropic light access. However, for seedlings, lower branches, or trees at the edge of a group, access to vertical light is limited and oblique growth is necessary. For oblique growth to occur, posture control by dissymmetric maturation strains is needed throughout growth (including, eventually, a dissymmetry of radial growth). Dissymmetric normal wood can be used for small inclines, but for strongly oblique (near horizontal) branches, reaction wood, eventually with eccentric growth, is the rule. When light access is more or less isotropic (for both dominant and dominated trees), trees are usually vertical when there is no accidental event. Self weight is still a problem in terms of the risk of buckling, but the wind is the main source of force leading to bending of the tree.

\section{Full light availability}

If both oblique and vertical light are fully accessible, the crown can spread out freely, but the wind will have the maximum effect in this situation. A large stem, with a small slenderness ratio $(H / D<50)$, is the best solution against wind and buckling risk (Telewski, 1989; Pruyn et al., 2000; Kern et al., 2005). Wood mechanical performances are marginal and very efficient trees can be built with light woods (Anten and Schieving, 2010; Larjavaara and Muller-Landau, 2010), which are efficient in terms of carbon economy for pioneer species.

\section{Vertical light availability}

If only vertical light is accessible, as in regular even-aged plantations, the crown width will be restricted by the density of trees and most trees will be co-dominant, so wind exposure is smaller than for open-field trees. In the race to keep a good height, with a rather small crown, high slenderness ratios (values between 50 and 100) and low density are good choices, as long as the self buckling risk is not too great. The risk of buckling is highest at a critical diameter $(20-30 \mathrm{~cm}$ for the abovementioned slenderness) and the way to limit this risk is to maximize the specific modulus while maintaining a good wood density in order to resist wind action. This is a classical strategy in high-density stands (Poorter et al., 2005; Read et al., 2011; Waghorn and Watt, 2013; Carson et al., 2014).

\section{No light availability}

Sometimes there is no direct access to light, for example, in the case of future dominant trees growing in the understorey, in very small gaps, at the beginning of life. Only a low percentage of the full light intensity is available near the ground and so the sapling must reach a rather great height (at least $10 \mathrm{~m}$ ) as soon as possible (Poorter et al., 2005). The only solution is to have a very high slenderness ratio (values $\sim 200$, often until the tree is
$20 \mathrm{~m}$ tall) as has been observed in tropical forest (Jaouen et al., 2007); trees with such high ratios have a very high buckling risk. The crown weight should be very small, and the only trees to be measured as having such high slenderness ratios have the highest specific modulus and high wood density.

\section{Coping with accidents}

There are two main kind of major accidents: (i) departure from verticality due to either partial uprooting (wind action) or ground instability, and (ii) top stem breakage (e.g. due to a heavy object falling on the stem or an animal eating it).

\section{Departure from verticality}

Under a combination of strong winds and wet soils, trees will often undergo a small permanent rotation of the whole root system so they are more or less inclined. In such circumstances, the risk of losing in the competition for light is great, and some quick vertical restoration is needed. The motion velocity is strongly regulated by diameter, and verticality of small-diameter trees is easily restored using reaction wood. To complement the use of reaction wood on one side, dissymmetry of growth can arise (Fig. 3A). Depending on the species, dissymmetry of maturation strain is four to six times more efficient than dissymmetry of growth (Alméras et al., 2005b; Huang et al., 2010). The use of buttresses (Fig. 3B) on the tensile side (Ter Steege et al., 1997; Fournier et al., 2014) is an extreme example of growth dissymmetry.

\section{Stem apex suppression}

Primary growth by the apex is the means by which trees reach higher. Branches below the apex use oblique growth in order to find lateral light. After apex breakage, the fastest way for the tree to regain height is to change the posture of one or more long thin branches near the breakage zone. The mechanism applied to the branch is the same as that used in restoring stem verticality, using reaction wood (Chanson et al., 1990) and section ovalization if needed. This option for a branch to take the lead in primary growth is also used by saplings in response to canopy disturbance (Collet et al., 2011) or by large inclined trees. Instead of restoring the verticality of a large stem, one of the branches on the upper side begins to grow vertically and the former apex part slowly declines. After such branch relay, the stem base continues to grow in an oblique fashion with a dissymmetry of maturation strain, while primary growth of the main branch limits the increase in flexure moment. This is probably the reason why strongly inclined large trees do not have very high maturation strains (Jullien et al., 2013).

\section{Conclusion}

The mechanical role of wood in a tree is much more complex than purely as a skeleton assuming the passive ascent of sap and resistance to gravity and external forces such as wind. In fact, 
wood in the tree, considered to be all the tissues underneath the bark, consists of a succession of dead skeleton (heartwood) and living skeleton (sapwood) where most of the cells are dead and representing the near totality of wood dry mass. However, this skeleton is surrounded by a continuous thin sleeve of living cells performing the additive manufacturing of the tree and creating forces that are useful for posture control.

Additive manufacturing parameters are the most important for hydraulic and structural mechanical resistance. Active force generation is compulsory and is precisely regulated around the stem and branches in answer to posture control and movements within the tree. Fibre wall structure and chemical composition are designed for force generation efficiency and for mechanical properties of the skeleton.

There is a very fine regulation of all living wood parameters: primary and secondary growth, secondary cell wall thickness and mechanical properties, as well as active force generation. How this regulation is proceeded by billions of wood living cells is puzzling (Coutand, 2010), although it is known that each cell is a kind of microprocessor, having sensors, memory, and an internal clock, and is able to act and send information through (at least) the giant web of parenchyma cells. Understanding this regulation will be a very great challenge that requires cooperation between engineering and biological sciences.

\section{References}

Abe H, Funada R, Ohtani J, Fukazawa K. 1997. Changes in the arrangement of cellulose microfibrils associated with the cessation of cell expansion in tracheids. Trees - Structure and Function 11, 328-332.

Alméras T, Clair B. 2016. Critical review on the mechanisms of maturation stress generation in trees. Journal of the Royal Society, Interface $\mathbf{1 3}$ 20160550.

Alméras T, Derycke M, Jaouen G, Beauchêne J, Fournier M. 2009. Functional diversity in gravitropic reaction among tropical seedlings in relation to ecological and developmental traits. Journal of Experimental Botany 60, 4397-4410.

Alméras T, Fournier M. 2009. Biomechanical design and long-term stability of trees: morphological and wood traits involved in the balance between weight increase and the gravitropic reaction. Journal of Theoretical Biology 256, 370-381.

Alméras T, Gril J, Yamamoto H. 2005a. Modelling anisotropic maturation strains in wood in relation to fibre boundary conditions, microstructure and maturation kinetics. Holzforschung 59, 347-353.

Alméras T, Jullien D, Gril J. 2018. Modelling, evaluation and biomechanical consequences of growth stress profiles i nside t ree $s$ tems. I n: Geitmann A, Gril J, eds, Plant biomechanics - from structure to function at multiple scales. Cham: Springer, 21-48.

Alméras T, Thibaut A, Gril J. 2005b. Effect of circumferential heterogeneity of wood maturation strain, modulus of elasticity and radial growth on the regulation of stem orientation in trees. Trees - Structure and Function 19, 457-467.

Anten NP, Schieving F. 2010. The role of wood mass density and mechanical constraints in the economy of tree architecture. The American Naturalist 175, 250-260.

Archer RR. 1986. Growth stresses and strains in trees. New York: Springer. Baillères H, Chanson B, Fournier M, Tollier MT, Monties B. 1995. Wood structure, chemical composition and growth strains in Eucalyptus clones. Annals of Forest Science 52, 157-172. (in French)

Bamber RK. 2001. A general theory for the origin of growth stresses in reaction wood: how trees stay upright. IAWA Journal 22, 205-212.
Barthélémy D, Caraglio Y. 2007. Plant architecture: a dynamic, multilevel and comprehensive approach to plant form, structure and ontogeny. Annals of Botany 99, 375-407.

Beeckman H. 2016. Wood anatomy and trait-based ecology. IAWA Journal 37, 127-151.

Becker G, Beimgraben T. 2001. Occurrence and relevance of growth stresses in Beech (Fagus sylvatica L.) in Central Europe. Final Report of FAIR-project CT 98-3606. Freiburg: Institut für Forstbenutzung und Forstliche Arbeitwissenschaft, Albert-Ludwigs Universität.

Björklund J, Seftigen K, Schweingruber F, Fonti P, von Arx G, Bryukhanova MV, Cuny HE, Carrer M, Castagneri D, Frank DC. 2017. Cell size and wall dimensions drive distinct variability of earlywood and latewood density in Northern Hemisphere conifers. New Phytologist 216, 728-740.

Boyd JD. 1950. Tree growth stresses. Part III. The origin of growth stresses. Australian Journal of Scientific Research Series B 3, 294-309.

Boyd JD. 1972. Tree growth stresses. Part V. Evidence and origin in differentiation and lignification. Wood Science and Technology 6, 251-262.

Brémaud I, Ruelle J, Thibaut A, Thibaut B. 2013. Changes in vibrational properties between compression and normal wood, roles of microfibril angle and of lignin. Holzforschung 67, 75-85.

Brennan M, McLean JP, Altaner CM, Ralph J, Harris PJ. 2012. Cellulose microfibril angles and cell-wall polymers in different wood types of Pinus radiata. Cellulose 19, 1385-1404.

Burgert I. 2006. Exploring the micromechanical design of plant cell walls. American Journal of Botany 93, 1391-1401.

Carson S, Cown D, McKinley R, Moore J. 2014. Effects of site, silviculture and seedlot on wood density and estimated wood stiffness in radiate pine at mid-rotation. New Zealand Journal of Forestry Science 44, 26.

Cave ID. 1969. The longitudinal Young's modulus of Pinus radiata. Wood Science and Technology 3, 40-48.

Chanson B, Loup C, Fournier M. 1990. Relationship between architecture, biomechanics and anatomy of the tree - case of a maritime pine. Tree: biology and development. Proceedings of the 2nd International Congress on the Tree, 10-15 September 1990, Montpellier. (in French)

Clair B, Alméras T, Pilate G, Jullien D, Sugiyama J, Riekel C. 2011. Maturation stress generation in poplar tension wood studied by synchrotron radiation microdiffraction. Plant Physiology 155, 562-570.

Clair B, Alteyrac J, Gronvold A, Espejo J, Chanson B, Alméras T. 2013. Patterns of longitudinal and tangential maturation stresses in Eucalyptus nitens plantation trees. Annals of Forest Science 70, 801-811.

Clair B, Ruelle J, Beauchêne J, Prévost MF, Fournier M. 2006. Tension wood and opposite wood in 21 tropical rain forest species. 1. Occurrence and efficiency of the G-layer. IAWA Journal 27, 329-338.

Collet C, Fournier M, Ningre F, Hounzandji AP, Constant T. 2011. Growth and posture control strategies in Fagus sylvatica and Acer pseudoplatanus saplings in response to canopy disturbance. Annals of Botany 107, 1345-1353.

Côté WA, Day AC, Timell TE. 1969. A contribution to the ultrastructure of tension wood fibers. Wood Science and Technology 3, 257-271.

Courtois-Moreau CL, Pesquet E, Sjödin A, Muñiz L, Bollhöner B, Kaneda M, Samuels L, Jansson S, Tuominen H. 2009. A unique program for cell death in xylem fibers of Populus stem. The Plant Journal $\mathbf{5 8}$ 260-274.

Coutand C. 2010. Mechanosensing and thigmomorphogenesis, a physiological and biomechanical point of view. Plant Science 179, 168-182.

Coutand C, Fournier M, Moulia B. 2007. The gravitropic response of poplar trunks: key roles of prestressed wood regulation and the relative kinetics of cambial growth versus wood maturation. Plant Physiology 144, 1166-1180.

Cruiziat P, Cochard H, Améglio T. 2002. Hydraulic architecture of trees: main concepts and results. Annals of Forest Science 59, 723-752.

Čufar K, Cherubini M, Gricar J, Prislan P, Spina S, Romagnoli M. 2011. Xylem and phloem formation in chestnut (Castanea sativa Mill.) during the 2008 growing season. Dendrochronologia 29, 127-134.

Cuny HE. 2013. Intra-year dynamics of wood formation for three conifer species: Silver fir, Norway spruce, Scots pine in the Vosges region. Doctoral thesis, Université de Lorraine, Nancy, France. 
Cuny HE, Rathgeber CB, Frank D, Fonti P, Fournier M. 2014. Kinetics of tracheid development explain conifer tree-ring structure. New Phytologist 203, 1231-1241.

Cuny HE, Rathgeber CB, Lebourgeois F, Fortin M, Fournier M. 2012. Life strategies in intra-annual dynamics of wood formation: example of three conifer species in a temperate forest in north-east France. Tree Physiology 32, 612-625.

Dadswell HE, Wardrop AB. 1955. The structure and properties of tension wood. Holzforschung 9, 97-103.

Déjardin A, Laurans F, Arnaud D, Breton C, Pilate G, Leplé JC. 2010. Wood formation in Angiosperms. Comptes Rendus Biologies 333, 325-334.

Dlouhá J, Alméras T, Beauchêne J, Clair B, Fournier M. 2018. Biophysical dependences among functional wood traits. Functional Ecology 32, 2652-2665.

Donaldson L. 2008. Microfibril angle, measurement, variation and relationships - a review. IAWA Journal 29, 345-386.

Fagerstedt KV, Mellerowicz E, Gorshkova T, Ruel K, Joseleau JP. 2014. Cell wall polymers in reaction wood. In: Gardiner B, Barnett J, Saranpää P, Gril J, eds. The biology of reaction wood. Heidelberg: Springer, 37-106.

Fahlén J, Salmén L. 2002. On the lamellar structure of the tracheid cell wall. Plant Biology 4, 339-345.

Fang CH, Clair B, Gril J, Liu SQ. 2008. Growth stresses are highly controlled by the amount of G-layer in poplar tension wood. IAWA Journal $\mathbf{2 9}$, 237-246.

Fisher JB, Stevenson JW. 1981. Occurrence of reaction wood in branches of dicotyledons and its role in tree architecture. Botanical Gazette 142, 82-95.

Fonti P, von Arx G, García-González I, Eilmann B, Sass-Klaassen U, Gärtner H, Eckstein D. 2010. Studying global change through investigation of the plastic responses of xylem anatomy in tree rings. New Phytologist 185, 42-53.

Forest Products Laboratory. 2010. Wood handbook: Wood as an engineering material. General Technical Report FPL-GTR-190. Madison: Forest Products Laboratory, USDA, Forest Service.

Fournier M, Alméras T, Clair B, Gril J. 2014. Biomechanical action and biological functions. In: Gardiner B, Barnett J, Saranpää P, Gril J, eds, The biology of reaction wood. Heidelberg: Springer, 139-170.

Fournier M, Bailleres H, Chanson B. 1994a. Tree biomechanics: growth, cumulative prestresses, and reorientations. Biomimetics 2, 229-251.

Fournier M, Chanson B, Guitard D, Thibaut B. 1991a. Mechanics of standing trees, modelling a growing structure subjected to continuous and fluctuating loads. 1. Analysis of support stresses. Annals of Forest Science 48, 513-525. (in French)

Fournier M, Chanson B, Thibaut B, Guitard D. 1994b. Measurements of residual growth strains at the stem surface observations on different species. Annals of Forest Science 51, 249-266. (in French)

Fournier M, Chanson B, Thibaut B, Guitard D. 1991b. Mechanics of standing trees, modelling a growing structure subjected to continuous and fluctuating loads. 2. Three-dimensional analysis of maturation stresses in a standard broadleaved tree. Annals of Forest Science 48, 527-546. (in French)

Fournier M, Dlouhá J, Jaouen G, Almeras T. 2013. Integrative biomechanics for tree ecology: beyond wood density and strength. Journal of Experimental Botany 64, 4793-4815.

Gardiner B, Barnett J, Saranpää P, Gril J. 2014. The biology of reaction wood. Heidelberg: Springer.

Gibson LJ. 2012. The hierarchical structure and mechanics of plant materials. Journal of the Royal Society, Interface 9, 2749-2766.

Gibson LJ, Ashby MF. 1997. Cellular solids, structure and properties, 2nd ed. Cambridge: Cambridge University Press.

Glass SV, Zelinka SL. 2010. Moisture relations and physical properties of wood. In Wood handbook: Wood as an engineering material. General Technical Report FPL-GTR-190. Madison: Forest Products Laboratory, USDA, Forest Service.

Gorshkova T, Brutch N, Chabbert B, Deyholos M, Hayashi T, LevYadun S, Mellerowicz EJ, Morvan C, Neutelings G, Pilate G. 2012.
Plant fiber formation: state of the art, recent and expected progress, and open questions. Critical Review in Plant Sciences 31, 201-228.

Gorshkova T, Chernova T, Mokshina N, Ageeva M, Mikshina P. 2018. Plant 'muscles': fibers with a tertiary cell wall. New Phytologist 218, 66-72.

Harrington JJ. 2002. Hierarchical modelling of softwood hygro-elastic properties. PhD thesis, University of Canterbury, New Zealand.

Harrington JJ, Booker RE, Astley RJ. 1998. Modelling the elastic properties of softwood. Part I: The cell-wall lamellae. European Journal of Wood and Wood Products 56, 37-41.

Huang YS, Chen SS, Kuo-Huang LL, Lee CM. 2005. Growth strain in the trunk and branches of Chamaecyparis formosensis and its influence on tree form. Tree Physiology 25, 1119-1126.

Huang YS, Hung LF, Kuo-Huang LL. 2010. Biomechanical modeling of gravitropic response of branches: roles of asymmetric periphery growth strain versus self-weight bending effect. Trees - Structure and Function 24, 1151-1161.

Jaouen G, Alméras T, Coutand C, Fournier M. 2007. How to determine sapling buckling risk with only a few measurements. American Journal of Botany 94, 1583-1593.

Jourez B, Riboux A, Leclercq A. 2001. Anatomical characteristics of tension wood and opposite wood in young inclined stems of poplar Populus euramericana cv 'Ghoy'. IAWA Journal 22, 133-157.

Jullien D, Gril J. 2008. Growth strain assessment at the periphery of smalldiameter trees using the two-grooves method: influence of operating parameters estimated by numerical simulations. Wood Science and Technology 42, 551-565.

Jullien D, Widmann R, Loup C, Thibaut B. 2013. Relationship between tree morphology and growth stress in mature European beech stands. Annals of Forest Science 70, 133-142.

Kellogg RM, Wangaard F. 1969. Variation in the cell-wall density of wood. Wood and Fiber Science 3, 180-204.

Kern KA, Ewers FW, Telewski FW, Koehler L. 2005. Mechanical perturbation affects conductivity, mechanical properties and aboveground biomass of hybrid poplars. Tree Physiology 25, 1243-1251.

Kretschmann DE. 2010. Mechanical properties of wood. In Wood handbook: Wood as an engineering material. General Technical Report FPL-GTR-190. Madison: Forest Products Laboratory, USDA, Forest Service.

Kübler H. 1959a. Studies of growth stresses in trees. Part 1. The origin of growth stresses and the stresses in the transverse direction. European Journal of Wood and Wood Products 17, 1-9. (in German)

Kübler H. 1959b. Studies of growth stresses in trees. Part 2. Longitudinal stresses. European Journal of Wood and Wood Products 17, 44-54. (in German)

Kübler H. 1987. Growth stresses in trees and related wood properties. Forestry Abstracts 10, 61-119.

Larjavaara M, Muller-Landau HC. 2010. Rethinking the value of high wood density. Functional Ecology 24, 701-705.

Leonardon M, Altaner CM, Vihermaa L, Jarvis MC. 2010. Wood shrinkage, influence of anatomy, cell wall architecture, chemical composition and cambial age. European Journal of Wood and Wood Products 68, 87-94.

Mellerowicz EJ, Baucher M, Sundberg B, Boerjan W. 2001. Unravelling cell wall formation in the woody dicot stem. Plant Molecular Biology 47, 239-274.

Mellerowicz EJ, Gorshkova TA. 2012. Tensional stress generation in gelatinous fibres: a review and possible mechanism based on cell-wall structure and composition. Journal of Experimental Botany 63, 551-565.

Mellerowicz EJ, Sundberg B. 2008. Wood cell walls: biosynthesis, developmental dynamics and their implications for wood properties. Current Opinion in Plant Biology 11, 293-300.

Moulia B, Coutand C, Lenne C. 2006. Posture control and skeletal mechanical acclimation in terrestrial plants: implications for mechanical modeling of plant architecture. American Journal of Botany 93, 1477-1489.

Moulia B, Fournier M. 2009. The power and control of gravitropic movements in plants: a biomechanical and systems biology view. Journal of Experimental Botany 60, 461-486. 
Okuyama T, Yamamoto H, Yoshida M, Hattori Y, Archer RR. 1994. Growth stresses in tension wood, role of microfibrils and lignification. Annals of Forest Science 51, 291-300.

Onaka F. 1949. Studies on compression- and tension-wood. Bulletin of the Wood Research Institute, Kyoto University 24, 1-88.

Plomion C, Leprovost G, Stokes A. 2001. Wood formation in trees. Plant Physiology 127, 1513-1523.

Poorter L, Bongers F, Sterk FJ, Wöll H. 2005. Beyond the regeneration phase: differentiation of height-light trajectories among tropical tree species. Journal of Ecology 93, 256-267.

Pruyn ML, Ewers BJ, Telewski FW. 2000. Thigmomorphogenesis: changes in the morphology and mechanical properties of two Populus hybrids in response to mechanical perturbation. Tree Physiology 20 , 535-540.

Raven PH, Evert RF, Eichhorn SE. 2007. The biology of plants. Brussels: De Boeck.

Read J, Evans R, Sanson GD, Kerr S, Jaffré T. 2011. Wood properties and trunk allometry of co-occurring rainforest canopy trees in a cycloneprone environment. American Journal of Botany 98, 1762-1772.

Ruelle J, Clair B, Beauchêne J, Prévost MF, Fournier M. 2006. Tension wood and opposite wood in 21 tropical rain forest species. 2. Comparison of some anatomical and ultrastructural criteria. IAWA Journal 27, 341-376.

Ruelle J, Yamamoto H, Thibaut B. 2007. Growth stresses and cellulose structural parameters intension and normal wood from three tropical rainforest angiosperm species. BioResources 2, 235-251.

Salmén L, Olsson AM, Stevanic J, Simonović J, Radotić K. 2012. Structural organisation of the wood polymers in the wood fibre structure. BioResources 7, 521-532.

Sinnott EW. 1952. Reaction wood and the regulation of tree form. American Journal of Botany 39, 69-78.

Sultana RS, Ishiguri F, Yokota S, lizuka K, Hiraiwa T, Yoshizawa N. 2010. Wood anatomy of nine Japanese hardwood species forming reaction wood without gelatinous fibers. IAWA Journal 31, 191-202.

Tanaka F, Koshijima T, Okamura K. 1981. Characterization of cellulose in compression and opposite woods of a Pinus densiflora tree grown under the influence of strong wind. Wood Science and Technology 15, 265-273.

Telewski FW. 1989. Structure and function of flexure wood in Abies fraseri. Tree Physiology 5, 113-121.
Ter Steege H, Ter Welle BJH, Lammg PB. 1997. The possible function of buttresses in Caryocar nuciferum (Caryocaraceae) in Guyana: ecological and wood anatomical observations. IAWA Journal 18, 415-431.

Thibaut B, Gril J, Fournier M. 2001. Mechanics of wood and trees, some new highlights for an old story. Comptes Rendus de l'Académie des Sciences Paris, Série II B 329, 701-716.

Timell TE. 1986. Compression wood in gymnosperms, Vol. 3. Berlin: Springer.

Vieilledent G, Fischer FJ, Chave J, Guibal D, Langbour P, Gérard J. 2018. New formula and conversion factor to compute basic wood density of tree species using a global wood technology database. American Journal of Botany 105, 1653-1661.

Waghorn MJ, Watt MS. 2013. Stand variation in Pinus radiata and its relationship with allometric scaling and critical buckling height. Annals of Botany 111, 675-680.

Wheeler EA, Baas P. 1998. Wood identification - a review. IAWA Journal 19, 241-264.

Wiedenhoeft A. 2010. Structure and function of wood. In Wood handbook: Wood as an engineering material. General Technical Report FPL-GTR-190. Madison: Forest Products Laboratory, USDA, Forest Service.

Wilson BF, Archer RR. 1977. Reaction wood: induction and mechanical action. Annual Review of Plant Physiology 28, 23-43.

Wong KV, Hernandez A. 2012. A review of additive manufacturing. ISRN Mechanical Engineering 2012, 208760.

Yang JL, Baillères H, Okuyama T, Muneri A, Downes G. 2005. Measurement methods for longitudinal surface strain in trees: a review. Australian Forestry 68, 34-43.

Yeh TF, Braun JL, Goldfarb B, Chang HM, Kadla JF. 2006. Morphological and chemical variations between juvenile wood, mature wood, and compression wood of loblolly pine (Pinus taeda L.). Holzforschung 60, 1-8.

Yeh TF, Goldfarb B, Chang HM, Peszlen I, Braun JL, Kadla JF. 2005. Comparison of morphological and chemical properties between juvenile wood and compression wood of loblolly pine. Holzforschung 59, 669-674.

Yoshida M, Okuda T, Okuyama T. 2000. Tension wood and growth stress induced by artificial inclination in Liriodendron tulipifera Linn. and Prunus spachiana Kitamura f. ascendens Kitamura. Annals of Forest Science $\mathbf{5 7}$ 739-746.

Yoshida M, Okuyama T. 2002. Techniques for measuring growth stress on the xylem surface using strain and dial gauges. Holzforschung 56, 461-467. 